\title{
Analisis Potensi Pakan untuk Pengembangan Ternak Ruminansia di Provinsi Jawa Timur
}

\author{
Analysis of Feed Potency for Development of Ruminant Livestock in East Java Province
}

\author{
D. N. Edi \\ Seksi Pembibitan Ternak dan Hijauan Makanan Ternak, UPT Pembibitan Ternak dan Kesehatan \\ Hewan di Madura, Dinas Peternakan Provinsi Jawa Timur, Pamekasan 69383, Jawa Timur, Indonesia \\ Corresponding email: didiknuredi@yahoo.co.id
}

\begin{abstract}
The purpose of this study was to analyze the feed potency for development of ruminant livestock in East Java Province. The data used in the analysis were secondary data from the Livestock Service Office and the Central Bureau of Statistics of East Java Province. The data were analyzed by using descriptive analysis. This method was done by collecting secondary data from related agencies, then compiled and analyzed into information that can be explained. The results showed that East Java Province had a population of ruminant livestock (beef cattle, dairy cows, buffaloes, goats and sheep) as many as 3,892,540 animal unit. The feed potency in East Java Province was 16,167,651 tons dry matter/year, consisting of 2,217,979 tons of dry matter/year of natural feed (grass) and 13,949,672 tons dry matter/year of agricultural by-products (straw). Livestock capacity reached 4,869,774 animal unit, which mean that it had a development potential of 977,234 animal unit. The value of Carrying Capacity Index in East Java Province is 1.3. In conclusion, the feed potency in East Java Province is included into critical criteria, which means that ruminant livestock have had the choice to utilize feed resources, but the conservation aspects have not yet been fulfilled.
\end{abstract}

Key words: ruminants, feed potency, development, carrying capacity index.

\begin{abstract}
ABSTRAK
Tujuan dari penelitian ini adalah untuk mengevaluasi potensi pakan untuk pengembangan ternak ruminansia di Provinsi Jawa Timur. Data yang digunakan dalam analisis adalah data sekunder dari Dinas Peternakan Provinsi Jawa Timur dan Badan Pusat Statistik Provinsi Jawa Timur. Metode analisis data yang digunakan adalah deskriptif analitis. Metode ini dilakukan dengan mengumpulkan data sekunder dari dinas terkait kemudian disusun dan dianalisis menjadi informasi yang dapat dijelaskan. Hasil penelitian menunjukkan bahwa Provinsi Jawa Timur memiliki populasi ternak ruminansia (sapi potong, sapi perah, kerbau, kambing dan domba) sebanyak 3.892.540 satuan ternak. Potensi pakan di Provinsi Jawa Timur adalah 16.167.651 ton bahan kering/tahun yang terdiri atas 2.217.979 ton bahan kering/tahun pakan alami (rumput) dan 13.949.672 ton bahan kering/tahun hasil samping pertanian (jerami). Daya tampung ternak mencapai 4.869.774 satuan ternak, yang berarti bahwa terdapat potensi pengembangan sebesar 977.234 satuan ternak. Nilai Indek Daya Dukung Pakan di Provinsi Jawa Timur adalah 1,3. Dapat disimpulkan bahwa potensi pakan di Provinsi Jawa Timur termasuk dalam kriteria kritis, yang berarti bahwa ternak ruminansia telah mempunyai pilihan untuk memanfaatkan sumber daya pakan tetapi aspek konservasinya belum terpenuhi.
\end{abstract}

Kata kunci: ruminansia, potensi pakan, pengembangan, indeks daya dukung pakan.

\section{PENDAHULUAN}

Provinsi Jawa Timur memeliki luas wilayah $47.799,75 \mathrm{~km}^{2}$ dengan jumlah penduduk mencapai 39.699 orang dengan laju pertumbuhan penduduk 0,64\% per tahun (BPS Provinsi Jawa Timur, 2020). Untuk memenuhi kebutuhan protein hewani bagi penduduk yang besar ini diperlukan pengembangan peternakan yang tepat. Salah satu sub sektor peternakan yang dapat mendukung asupan protein hewani dari daging adalah peternakan ruminansia.
Populasi ternak ruminansia (sapi potong, sapi perah, kerbau, kambing dan domba) di Provinsi Jawa Timur saat ini mencapai 3,89 juta satuan ternak (ST). Dalam rangka menunjang produktivitas ternak ruminansia dan untuk melihat proyeksi pengembangan ternak ruminansia diwilayah yang sesuai dengan ketersediaan pakan hijauan, diperlukan analisis potensi pakan dan indek daya dukung pakan guna pembangunan sub sektor peternakan yang tepat. Selain itu analisis potensi pakan salah satunya dapat digunakan untuk mengatasi kekurangan hijauan pakan ternak (HPT) pada 
musim kemarau dengan melihat ketersediaan pakan lokal yang disesuaikan dengan jumlah ternak. Inventarisasi lahan yang dapat digunakan sebagai pengembangan peternakan sangat perlu hal ini untuk menentukan ketertersedia hijauan pakan ternak dan untuk menganalisa kapasitas ternak yang dapat ditempatkan di wilayah tersebut (Atmiyati, 2006).

Pakan ternak ruminansia sebagian besar dari hijauan terdiri atas rumput, leguminosa dan dedaunan serta hasil samping produk pertanian. Menurut Saking dan Qomariyah (2017), pakan hijauan pada ruminansia mencapai $70 \%$ dari total pakan, sisanya adalah konsentrat. Bahkan peternak rakyat atau tradisional seluruh pakan ternak ruminansia berasal hijauan. Sehingga analisis potensi hijauan dan penempatan ternak pada wilayah yang tepat dapat mendukung produktivitas ternak yang baik.

Tujuan penulisan ini adalah untuk memberikan gambaran dan informasi potensi pengembangan ternak ruminansia disetiap wilayah Kabupaten di Provinsi Jawa Timur untuk keseimbangan daya dukung pakan dan kesesuaian lahan. Status keamanan pakan pada suatu wilayah merupakan salah satu faktor yang sangat penting serta turut mempengaruhi potensi pengembangan dan dinamika populasi dalam keberhasilan pengembangan ternak ruminansia.

\section{MATERI DAN METODE}

Data yang dianalisis adalah data sekunder dari Dinas terkait terutama dari Dinas Peternakan Provinsi Jawa Timur dan Badan Pusat Statistik Provinsi Jawa Timur tahun 2018, 2019 dan 2020. Metode analisis data yang digunakan adalah deskriptif analitis. Metode ini dilakukan dengan mengumpulkan data sekunder dari dinas terkait kemudian disusun dan dianalisis menjadi informasi yang dapat dijelaskan.

\section{Parameter}

1. Profil ternak ruminansia di Provinsi Jawa Timur. Penyeragaman ternak mengikuti Ashari et al. (1995) yaitu sapi 0,7 ST, kerbau 0,8 ST, domba 0,07 ST, kambing 0,08 ST.

2. Potensi hasil samping produk pertanian

Perhitungan mengikuti Tiwow et al., (2006) yang dimodifikasi :
Potensi limbah $=\quad($ pd $\times 0,4)+(j g \times 3 \times$

$0,5)+(\mathrm{kd} \times 3 \times 0,55)+\{(\mathrm{kh}+\mathrm{kt}) \times 2 \times 0,55\}$

$+\{(\operatorname{uj} \times 0,25 / 6)+($ uk x $0,25 / 4)\} \times 0,65$

Keterangan $\quad=$ pd (padi); jg (jagung); kd (kedelai); kh (kacang hijau); kt (kacang tanah); uj (ubi jalar); uk (ubi kayu).

3. Potensi hijauan alami (Tanuwiria et al., 2007):

Lahan sawah $=(0,77591 \times$ luas lahan $\mathrm{x} 0,06 \mathrm{x}$ $6,083)$ ton BK/tahun

Lahan kering $($ darat $)=(1,062 \times$ luas lahan $\mathrm{x}$ $0,09785 \times 6,083)$ ton $\mathrm{BK} /$ tahun

Lahan hutan $=(2,308 \times$ luas lahan $\mathrm{x} 0,05875 \mathrm{x}$ $6,083) \mathrm{BK} /$ tahun

4. Daya tampung ternak (ST)

Dihitung dengan $=\frac{\text { Total potensi pakan tersedia }}{3,32}$

Kebutuhan pakan untuk setiap ST adalah 9,1 kg bahan kering (BK)/hari atau 3,32 ton BK/tahun (Ashari et al., 1995).

5. Potensi pengembangan ternak (ST)

Dihitung dengan pendekatan $=$ kapasitas tampung - jumlah ternak.

6. Indek daya dukung wilayah (IDD) (Saputra $e t$ al., 2016).

IDD $=\frac{\text { Daya } T \text { ampung Ternak }(S T)}{\text { Jumlah Populasi Ternak }(S T)}$

Kriteria IDD

IDD $\leq 1$ (sangat kritis); IDD $>1-1,5$ (kritis); IDD >1,5 - 2 (rawan); IDD >2 (Aman)

\section{HASIL DAN PEMBAHAAN}

\section{Profil Ternak di Provinsi Jawa Timur}

Peternakan ruminansia di Provinsi Jawa Timur penyumbang daging sapi tertinggi di Indonesia, yaitu mencapai 99.340 ton per tahun atau sekitar $20 \%$ nasional, dan menyumbangkan total daging terbesar kedua setelah Jawa Barat yaitu sekitar 13,6\% nasional atau 490.044 ton per tahun terdiri atas daging ruminansia $22 \%$, unggas $74 \%$ dan lainnya $4 \%$ (Kementrian Pertanian, 2018). Sebaran populasi ternak ruminansia di Provinsi Jawa Timur ditampilkan pada Gambar 1. 


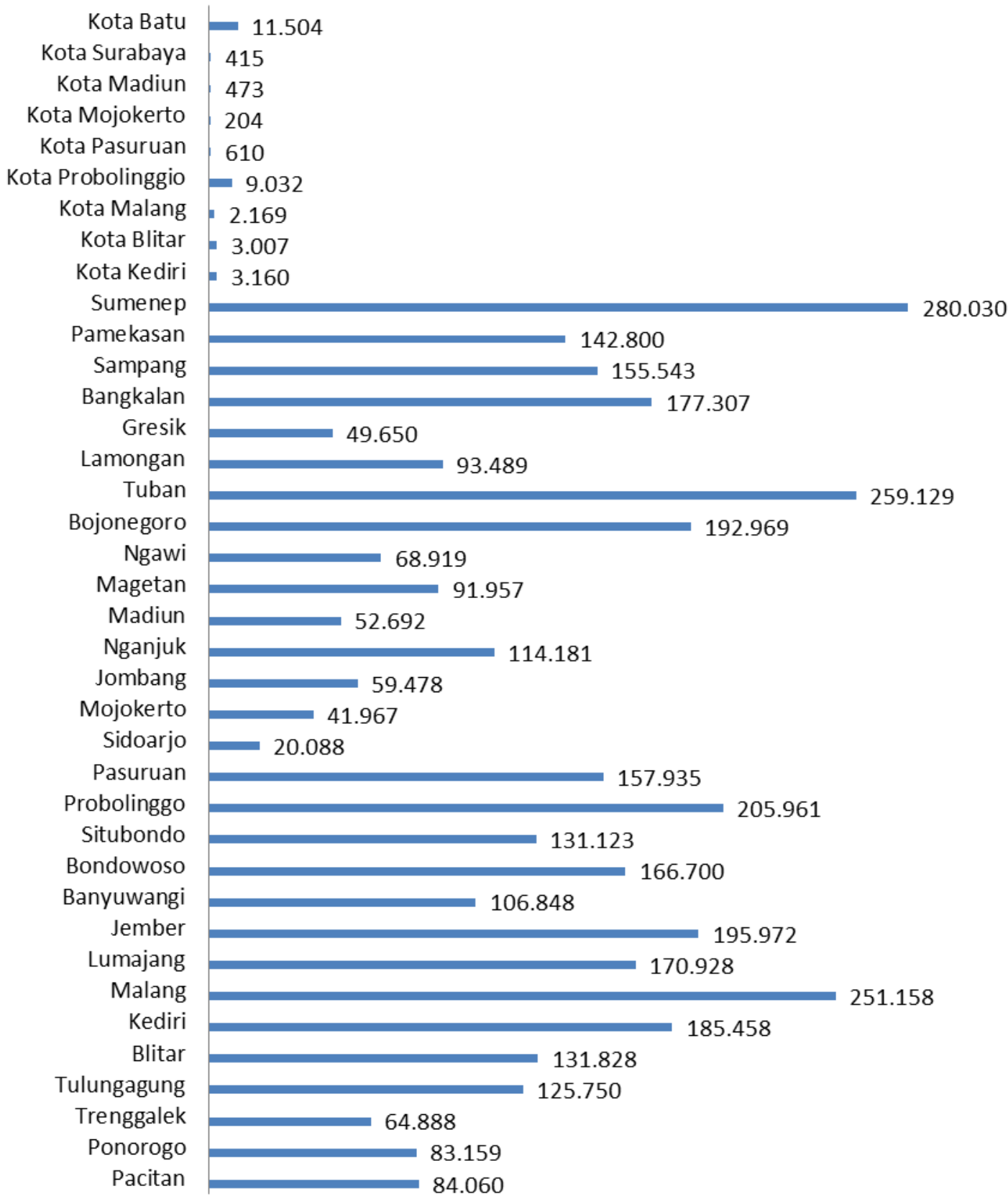

Gambar 1. Sebaran populasi ternak ruminansia di Provinsi Jawa Timur (ST)(Kementrian Pertanian, 2018).

Berdasarkan Gambar 1 menunjukkan bahwa populasi ternak ruminasia terbesar di Kabupaten Sumenep mencapai 280.030 ST dan terendah di Kota Mojokerto yaitu 204 ST. Melihat data tersebut dapat memberikan gambaran bahwa perlunya perencanaan dalam pengembangan peternakan ruminansia.

\section{Potensi Hasil Samping Produk Pertanian}

Hasil samping produk pertanian untuk pakan ternak ruminansia di Provinsi Jawa Timur sangatlah berpotensi besar untuk pakan ternak ruminansia, baik dilihat dari segi kuantitas maupun kualitasnya. Kuantitas bahan kering yang dapat dihasilkan dari produk samping tanaman produk pertanian mencapai 13.949.672 ton BK/tahun. Produk hasil samping terbanyak ada di Kabupaten Tuban yaitu 1.019.165 ton BK/tahun dan terendah di Kota Mojokerto yaitu 1.602 ton BK/tahun. Sebaran hasil samping produk pertanian di Provinsi Jawa Timur dapat dilihat pada Gambar 2.

Pemanfaatan hasil samping produk pertanian merupakan salah satu solusi untuk pemenuhan kebutuhan pakan hijauan bagi ternak ruminansia. Saputra et al., (2016) menyatakan 
bahwa pemanfaatan hasil samping produk pertanian untuk pakan ruminansia sudah dikenal luas karena kemampuan ternak ruminansia dapat mengkonversi bahan pakan yang mengandung serat kasar tinggi menjadi produk yang bermanfaat untuk pertumbuhan dan reproduksinya. Yusriani et al., (2015) menambahkan model integrasi tanaman ternak, petani mengatasi permasalahan ketersediaan pakan ternak dengan memanfaatkan limbah tanaman seperti jerami padi, jerami jagung dan limbah kacang-kacangan. Berdasarkan Gambar 2 pakan dari produk samping hasil pertanian dapat mencapai $85,5 \%$ dari total produksi pakan.

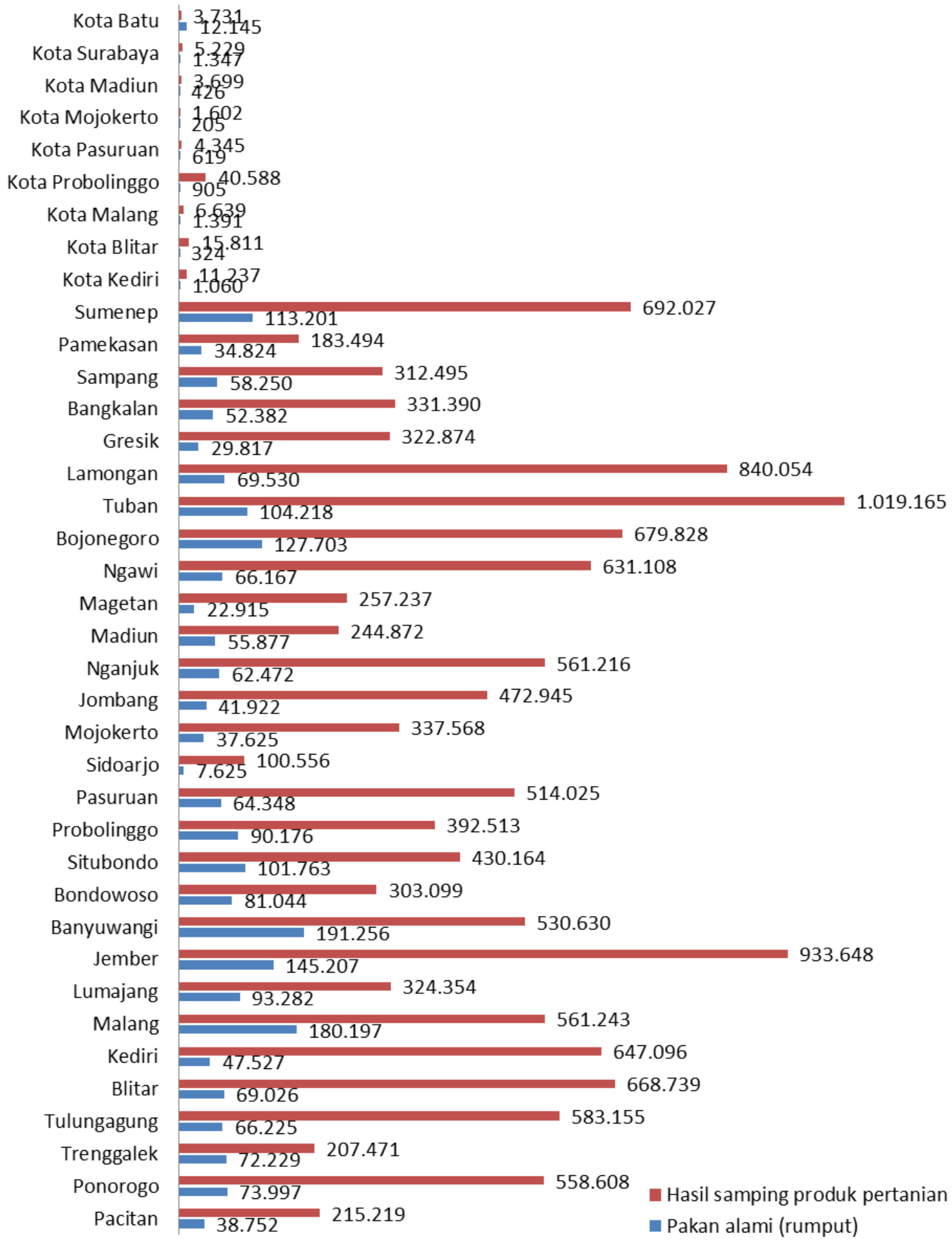

Gambar 2. Sebaran potensi pakan dari hasil samping produk pertanian dan hijauan alami (ton BK/tahun)(Kementrian Pertanian, 2018). 
Hasil samping tersebut dapat berupa jerami, kulit maupun bagian tanaman lainnya yang tidak dimanfaatkan untuk kebutuhan pangan. Kandungan nutrisi hasil samping beberapa produk pertanian disajikan pada Tabel 1.

Melihat kuantitas dan kualitasnya pada Gambar 2 dan Tabel 1, maka pemanfaatan hasil samping produk pertanian di Provinsi Jawa Timur sangatlah berpotensi untuk pakan ternak ruminansia. Ketersediaan bahan pakan ternak ditunjang oleh ketersediaan dan produksi tanaman pertanian berupa limbah dan hasil ikutannya, sedangkan produksi hasil pertanian selain dipengaruhi oleh keadaan iklim juga dipengaruhi oleh luas panen usaha tani, tenaga kerja dan banyaknya ternak yang dipelihara serta juga letak wilayah usahataninya (Sari et al., 2016).

\section{Potensi Hijauan Alami}

Hijauan alami yang dianalisis dalam tulisan ini adalah rumput lapang atau rumput liar yang tidak dibudidayakan secara intensif. Rumput tersebut secara alami tumbuh disekitar lahan pertanian (sawah dan tegal), hutan dan sekitar pekarangan rumah. Menurut Sumanto dan Juarini (2004), daya dukung pakan alami merupakan kemampuan penyediaan pakan ternak (hijauan) dari suatu wilayah administratif. Siba et al., (2017) menambahkan hijaun pakan alami tidak saja dapat ditemui pada padang penggembalaan alami tetapi pada berbagai kawasan lahan kosong yang sengaja maupun tidak sengaja memiliki potensi untuk penyediaan hijaun pakan alami. Kandungan nutrisi rumput alami adalah bahan kering 24,4\%, abu 14,5\%, protein kasar $8,2 \%$, lemak kasar 1,4\%, serat kasar 3,7\%, bahan ektrak tanpa nitrogen 44,2\% dan total digestible nutrient 56,2\% (Tanuwiria et al., 2007).

Potensi bahan kering hijauan alami berupa rumput di Provinsi Jawa Timur dalam setahun dapat mencapai 2.217.979 ton BK/tahun. Sebaran produksi bahan kering tiap Kabupaten/Kota di Provinsi Jawa Timur dapat dilihat pada Gambar 2. Potensi bahan kering yang dihasilkan dari rumput dapat menyumbang $14,5 \%$ dari total produksi pakan. Tubangsa (2018) menyatakan bahwa tingkat ketersediaan pakan hijauan ternak pada suatu wilayah

Tabel 1. Kandungan nutrien bahan pakan asal hasil samping produk pertanian

\begin{tabular}{|c|c|c|c|c|c|c|c|}
\hline Bahan pakan & KA & Abu & PK & LK & SK & $\mathrm{Ca}$ & $\mathrm{P}$ \\
\hline Jerami padi $^{1)}$ & 14,59 & 5,95 & 9,93 & 6,36 & 9,68 & 0,07 & 0,65 \\
\hline Tebon jagung ${ }^{1)}$ & 75,20 & 9,40 & 9,24 & 1,37 & 37,45 & 0,55 & 0,20 \\
\hline Tumpi jagung ${ }^{1)}$ & 11,30 & 4,20 & 8,40 & 2,69 & 13,72 & 0,36 & 0,26 \\
\hline Jerami jagung ${ }^{1)}$ & 14,11 & 13,20 & 16,22 & 2,55 & 23,50 & 0,46 & 0,41 \\
\hline Daun jagung ${ }^{1)}$ & 66,38 & 14,15 & 9,58 & 3,94 & 34,26 & 0,10 & 0,41 \\
\hline Daun kacang kedelai ${ }^{2)}$ & 87,4 & 10,10 & 16,70 & 3,7 & 27,7 & - & - \\
\hline Jerami kacang kedelai ${ }^{3)}$ & 60,62 & - & 14,09 & 3,54 & 20,96 & - & - \\
\hline Jerami kacang hijau ${ }^{3)}$ & 88,07 & - & 15,39 & 3,59 & 26,39 & - & - \\
\hline Akar kacang tanah ${ }^{1)}$ & 14,16 & 31,10 & 7,45 & 1,17 & 17,46 & 0,43 & 0,17 \\
\hline $\begin{array}{l}\text { Daun dan batang kacang } \\
\operatorname{tanah}^{1)}\end{array}$ & 12,63 & 9,7 & 8,61 & 1,86 & 35,14 & 1,22 & 0,32 \\
\hline Jerami kacang tanah $^{1)}$ & 16,80 & 12,00 & 19,92 & 1,96 & 29,57 & 1,85 & 0,23 \\
\hline Kulit kacang tanah ${ }^{1)}$ & 11,32 & 24,49 & 7,05 & 3,06 & 36,83 & 0,51 & 0,10 \\
\hline Daun ubi jalar²) & 23,7 & 16,1 & 19,2 & 2,6 & 16,2 & - & - \\
\hline Jerami ubi jalar ${ }^{3)}$ & 84,79 & - & 3,90 & 1,40 & 21,51 & - & - \\
\hline $\begin{array}{l}\text { Batang dan daun ubi } \\
\mathrm{kayu}^{2)}\end{array}$ & 9,86 & 6,20 & 24,98 & 5,77 & 33,74 & 1,03 & 0,32 \\
\hline Jerami ubi kayu ${ }^{3)}$ & 82,59 & - & 3,98 & 1,59 & 33,24 & - & - \\
\hline Daun ubi kayu ${ }^{4)}$ & 75,67 & 7,05 & 33,05 & 5,00 & 14,41 & 1,51 & 0,47 \\
\hline Kulit ubi kayu ${ }^{2)}$ & 40,47 & 8,28 & 6,01 & 1,25 & 21,01 & 0,46 & 0,16 \\
\hline
\end{tabular}


merupakan salah satu faktor yang sangat penting serta turut mempengaruhi dinamika populasi dalam keberhasilan pengembangan ternak.

\section{Daya Tampung Ternak dan Potensi Pengembangan}

Daya tampung ternak merupakan kemampuan suatu wilayah administratif untuk dapat menampung kebutuhan pakan ternak pada kurun waktu tertentu, berupa rumput alami dan hasil produk pertanian tanpa pengolahan. Daya tampung ternak dihitung dengan melihat populasi dalam suatu wilayah dibandingkan dengan potensi pakan yang dihasilkan pada wilayah tersebut dalam kurun waktu tertentu. Tubangsa (2018) mengkaji bahwa salah satu cara untuk mengetahui wilayah pengembangan peternakan, digunakan analisis spasial terhadap produksi peternakan berdasarkan daya dukung lahan.

Tabel 2. Daya tampung dan potensi pengembangan ternak diwilayah Provinsi Jawa Timur

\begin{tabular}{|c|c|c|c|c|c|}
\hline Kabupaten/Kota & $\begin{array}{l}\text { Produksi pakan } \\
\text { (ton BK/tahun) }\end{array}$ & $\begin{array}{c}\text { Daya } \\
\text { Tampung (ST) }\end{array}$ & $\begin{array}{c}\text { Potensi } \\
\text { pengembangan (ST) }\end{array}$ & IDD & Kriteria \\
\hline Pacitan & $253.077,0$ & 76.497 & -7.563 & 0,9 & sangat kritis \\
\hline Ponorogo & $605.363,3$ & 190.544 & 107.384 & 2,3 & aman \\
\hline Trenggalek & $270.645,5$ & 84.247 & 19.359 & 1,3 & kritis \\
\hline Tulungagung & $631.330,4$ & 195.596 & 69.846 & 1,6 & rawan \\
\hline Blitar & $711.493,3$ & 222.218 & 90.390 & 1,7 & rawan \\
\hline Kediri & $674.523,0$ & 209.224 & 23.766 & 1,1 & kritis \\
\hline Malang & $713.707,9$ & 223.326 & -27.832 & 0,9 & sangat kritis \\
\hline Lumajang & $397.643,7$ & 125.794 & -45.134 & 0,7 & sangat kritis \\
\hline Jember & $1.048 .395,5$ & 324.956 & 128.984 & 1,7 & rawan \\
\hline Banyuwangi & $686.501,8$ & 217.436 & 110.588 & 2,0 & aman \\
\hline Bondowoso & $377.147,1$ & 115.706 & -50.994 & 0,7 & sangat kritis \\
\hline Situbondo & $517.756,3$ & 160.219 & 29.096 & 1,2 & kritis \\
\hline Probolinggo & $474.241,8$ & 145.388 & -60.573 & 0,7 & sangat kritis \\
\hline Pasuruan & $564.718,4$ & 174.209 & 16.274 & 1,1 & kritis \\
\hline Sidoarjo & $74.269,2$ & 32.585 & 12.497 & 1,6 & rawan \\
\hline Mojokerto & $335.529,2$ & 113.010 & 71.043 & 2,7 & aman \\
\hline Jombang & $475.413,4$ & 155.080 & 95.602 & 2,6 & aman \\
\hline Nganjuk & $577.615,3$ & 187.858 & 73.677 & 1,6 & rawan \\
\hline Madiun & $252.058,3$ & 90.587 & 37.896 & 1,7 & rawan \\
\hline Magetan & $249.787,9$ & 84.383 & -7.574 & 0,9 & sangat kritis \\
\hline Ngawi & $600.775,3$ & 210.023 & 141.103 & 3,0 & aman \\
\hline Bojonegoro & $756.213,2$ & 243.232 & 50.263 & 1,3 & kritis \\
\hline Tuban & $1.075 .008,5$ & 338.368 & 79.240 & 1,3 & kritis \\
\hline Lamongan & $819.505,4$ & 273.971 & 180.482 & 2,9 & aman \\
\hline Gresik & $313.479,5$ & 106.232 & 56.582 & 2,1 & aman \\
\hline Bangkalan & $372.869,3$ & 115.594 & -61.713 & 0,7 & sangat kritis \\
\hline Sampang & $366.097,5$ & 111.670 & -43.873 & 0,7 & sangat kritis \\
\hline Pamekasan & $217.089,2$ & 65.759 & -77.041 & 0,5 & sangat kritis \\
\hline Sumenep & $798.012,7$ & 242.539 & -37.491 & 0,9 & sangat kritis \\
\hline Kota Kediri & $11.927,6$ & 3.704 & 544 & 1,2 & kritis \\
\hline Kota Blitar & $15.296,2$ & 4.860 & 1.853 & 1,6 & rawan \\
\hline Kota Malang & $5.999,9$ & 2.419 & 249 & 1,1 & kritis \\
\hline Kota Probolinggo & $41.081,0$ & 12.498 & 3.466 & 1,4 & kritis \\
\hline Kota Pasuruan & $4.238,6$ & 1.495 & 885 & 2,5 & aman \\
\hline Kota Mojokerto & $1.607,1$ & 544 & 340 & 2,7 & aman \\
\hline Kota Madiun & $3.099,9$ & 1.242 & 769 & 2,6 & aman \\
\hline Kota Surabaya & $5.755,3$ & 1.981 & 1.566 & 4,8 & aman \\
\hline Kota Batu & $15.249,0$ & 4.782 & -6.723 & 0,4 & sangat kritis \\
\hline Jawa Timur & $15.314 .523,3$ & 4.869.774 & 977.234 & 1,3 & kritis \\
\hline
\end{tabular}


Dengan melihat potensi pakan pada Gambar 2 dan populasi ternak pada Gambar 1 daya tampung ternak ruminansia di Provinsi Jawa Timur mencapai 4.869.774 ST, sedangkan populasi ternak ruminansianya adalah 3.892 .540 ST sehingga ada potensi pengembangan ternak ruminansia sekitar 977.234 ST. Nilai potensi pengembangan ini dapat diartikan bahwa wilayah Provinsi Jawa Timur masih mempunyai sumberdaya pakan yang belum dimanfaatkan secara maksimal. Sebaran daya tampung ternak dapat dilihat pada Tabel 2.

Pada Tabel 2 menunjukkan bahwa sebaran potensi pengembangan ternak ruminansia diwilayah Provinsi Jawa Timur tidak merata, beberapa Kabupaten memiliki potensi pengembangan yang besar disisi lain populasi ternak melebihi daya tampung pakannya. Data tersebut memberikan gambaran bahwa perlu adanya perencanaan dalam pengembangan usaha peternakan dengan menyesuaikan sumber daya pakan dengan populasi di masing-masing wilayah Kabupaten/Kota. Saputra (2016) menyatakan bahwa penambahan dan pengembangan tersebut disesuaikan dengan ekologis lahan serta pola pengembangan dapat dengan devesifikasi spasial, yaitu pengembangan pada lahan-lahan yang telah mempunyai peruntukan, antara lain untuk tanaman pangan dan perkebunan dalam bentuk pola keterpaduan, atau pola ekstensifikasi spasial, yaitu pengembangan pada lahan kehutanan dan alangalang.

Pada Tabel 2 memperlihatkan bahwa potensi pengembangan tertinggi dapat dilakukan di Kabuapten Lamongan yaitu 180.482 ST atau setara dengan 257.831 ekor sapi potong. Pada beberapa Kabupaten/Kota yang nilai pengembangannya negatif mengindikasikan bahwa sumberdaya pakan tidak mampu mencukupi kebutuhan pakan pada wilayah tersebut atau populasi ternak ruminansia melebihi daya tampung pakan pada wilayah tersebut.

\section{Indek Daya Dukung Wilayah (IDD)}

Indek daya dukung pakan merupakan suatu pendekatan untuk menilai pengembangan suatu wilayah. Angka IDD juga digunakan untuk mengetahui tingkat keamanan pakan ternak pada suatu wilayah guna mendukung kehidupan ternak yang berada di wilayah tersebut (Triyanto et al., 2018). Nilai IDD Provinsi Jawa Timur sekitar 1,3 hal tersebut menandakan bahwa ada pada kriteria "Kritis" artinya ternak ruminansia telah mempunyai pilihan untuk memanfaatkan sumber daya tetapi belum terpenuhi aspek konservasinya (Tiwow et al., 2016). Nilai IDD pada masing masing Kabupaten/Kota di Provinsi Jawa Timur ditampilkan pada Tabel 2.

Kriteria dan Nilai IDD merupakan salah satu indikator kunci untuk pengembangan ternak di wilayah tersebut, nilai IDD diatas 2 dengan kriteria "Aman" menunjukkan bahwa pada wilayah tersebut mempunyai daya dukung lahan yang baik atau populasi ternak ruminannya yang rendah. Sebaliknya nilai IDD rendah kurang dari satu $(<1)$ menunjukkan pada wilayah tersebut daya dukung pakannya rendah dengan populasi ternaknya yang tinggi. Menurut Saputra (2016) IDD memperlihatkan status masing-masing wilayah terhadap kemampuan penambahan populasi untuk ruminansia saat ini.

Melihat Tabel 2 menunjukkan beberapa wilayah Kabupaten/Kota yang mempunyai potensi untuk dikembangkan usaha peternakan ruminansia adalah Ponorogo, Banyuwangi, Mojokerto, Jombang, Ngawi, Lamongan, Gresik serta Kota Surabaya, Mojokerto, Madiun dan Pasuruan. Kabupaten/Kota yang memerlukan perhatian untuk menyeimbangkan populasi dan sumber daya pakannya adalah Kabupaten Pacitan, Malang, Lumajang, Bondowoso, Probolinggo, Magetan, Bangkalan, Sampang, Pamekasan, Sumenep serta Kota Batu.

\section{KESIMPULAN}

Provinsi Jawa Timur memiliki populasi ternak ruminansia (sapi potong, sapi perah, kerbau, kambing dan domba) sebanyak 3.892.540 ST dengan potensi pakan sebesar 16.167.651 ton BK/tahun terdiri atas pakan alami (rumput) sebesar 2.217.979 ton BK/tahun dan hasil samping pertanian (jerami) sebesar 13.949.651 ton BK/tahun. Daya tampung ternak mencapai 4.869.774 ST, sehingga mempunyai potensi pengembangan sebesar 977.234 ST. Nilai IDD di Provinsi Jawa Timur adalah 1,3 dengan kriteria kritis artinya ternak ruminansia telah mempunyai pilihan untuk memanfaatkan sumber daya tetapi belum terpenuhi aspek konservasinya.

\section{DAFTAR PUSTAKA}

Ashari, F., E. Juarini, Sumanto, B. Wibowo, dan Suratman. 1995. Pedoman analisis potensi wilayah penyebaran dan 
pengembangan peternakan. Balai Penelitian Ternak dan Direktorat Bina Penyebaran dan Pengembangan Peternakan. Jakarta.

Atmiyati. 2006. Daya dukung hijauan pakan terhadap pengembangan ternak di Kabupaten Sambas. Temu Teknis Nasional Tenaga Fungsional Pertanian 2006. Pusat Penelitian dan Pengembangan Peternakan.

Badan Pusat Statistik Provinsi Jawa Timur. 2018. Provinsi Jawa Timur dalam angka 2018. Provinsi Jawa Timur.

Badan Pusat Statistik Provinsi Jawa Timur. 2019. Provinsi Jawa Timur dalam angka 2019. Provinsi Jawa Timur.

Badan Pusat Statistik Provinsi Jawa Timur. 2020. Provinsi Jawa Timur dalam angka 2020. Provinsi Jawa Timur.

Balai Pengujian Mutu dan Sertifikasi Pakan Bekasi. 2013. Hasil uji bahan makanan dan hijauan pakan ternak. Balai Pengujian Mutu dan Sertifikasi Pakan Bekasi (BPMSP). Bekasi

Dewantari, M. 2016. Potensi limbah jerami serta pemanfaatan untuk makanan ternak. Karya Tulis. Fakultas Peternakan. Universitas Udayana. Denpasar.

Kementrian Pertanian. 2018. Statistik peternakan dan kesehatan hewan 2018. Direktorat Jenderal Peternakan dan Kesehatan Hewan Kementrian Pertanian RI.

Saking, N. dan N. Qomariyah. 2017. Identifikasi hijauan makanan ternak (HMT) lokal mendukung produktivitas sapi potong di Sulawesi Selatan. Prosiding Seminar Nasional Teknologi Peternakan dan Veteriner 2017. DOI: http://dx.doi.org/10.14334/Pros.Semnas. TPV-2017-p.558-565

Saputra, J. I. 2016. Analisis potensi daya dukung pengembangan peternakan sapi potong di Kabupaten Pesawaran. Skripsi. Fakultas Pertanian. Universitas Lampung. Bandar Lampung
Sari, A., Liman, dan Muhtarudin. 2016. Potensi daya dukung limbah tanaman palawija sebagai pakan ternak ruminansia di Kabupaten Pringsewu. Jurnal Ilmiah Peternakan Terpadu, 4(2): 100-107.

Siba, F. G., W. Suarna, dan N. N. Suryani. 2017. Evaluasi padang penggembalaan alami Maronggela di Kabupaten Ngada Provinsi Nusa Tenggara Timur. Majalah Ilmiah Peternakan, 2(1): 1-4.

Sumanto dan E. Juarini. 2004. Potensi kesesuaian lahan untuk pengembangan ternak ruminansia di Propinsi Nusa Tenggara Timur. Seminar Nasional Teknologi Peternakan dan Veteriner, pp. 123-129.

Tanuwiria, U. H., A. Mushawwir, dan A. Yulianti. 2007. Potensi pakan serat dan daya dukungnya terhadap populasi ternak ruminansia di wilayah Kabupaten Garut. Jurnal Ilmu Ternak, 7(2): 117-127.

Tiwow, H. A. L., V. V. J. Panelewen, dan A. D. Mirah. 2016. Analisis potensi daya dukung lahan untuk pengembangan sapi potong di kawasan Pakakaan Kabupaten Minahasa. Jurnal Zootek 35(2): 476-486.

Triyanto, E. S. Rahayu, dan S. H. Purnomo. 2018. Analisis daya dukung wilayah pengembangan sapi potong di Kabupaten Gunungkidul. Seminar Nasional Dalam Rangka Dies Natalis UNS Ke 42 Tahun 2018.

Tubangsa, I. 2018. Analisis potensi hijauan dan daya dukung wilayah dalam pengembangan ternak ruminansia kecil di Kota Parepare. Skripsi. Program Studi Pendidikan Geografi. Jurusan Geografi. Fakultas Ilmu Matematika dan Ilmu Pengetahuan Alam. Universitas Negeri Makasar.

Yusriani, Y., Elviwirda, dan M. Sabri. 2015. Kajian pemanfaatan limbah jerami sebagai pakan ternak sapi di Provinsi Aceh. Jurnal Peternakan Indonesia 17(2): $163-169$ 